\title{
District Authorities That Are in the Region Country Border in Managing Border Area
}

\author{
Robert Hoffman
}

\section{Universitas Sumatera Utara}

Email:tobingunka@gmail.com

\begin{abstract}
The Border Area as a strategic area in maintaining the territorial integrity requires special supervision. Seeing the life of the people in the border areas of the country which is still concerning, the sub-district which is part of the district/city area as their place of residence must of course be managed as well as possible. The purpose of this research is to find out how the authority of the sub-districts in the border areas of the country in managing the border areas. My research question is how the authority of sub-districts in the state border area in managing border areas? In this research, $\mathrm{i}$ applied a normative juridical research. The conclusions in this study are as follows : the condition of state border areas in Indonesia which is still concerning today is due to the centralize government and the overlapping State Territory Law and Regional Government Law so that it is unclear which authority will be used from the two laws. In addition, there are regulations regarding institutions that manage border areas, namely BPPD in the State Territory Law which are coordinating so that they do not have an impact on implementation the authority for sub districts in state border areas.
\end{abstract}

Keywords: Authority, District, Border.

\section{INTRODUCTION}

Indonesia is divided into provinces, districts and cities. Districts/municipalities are divided into districts and sub districts are divided into villages. Sub district areas is part a district/city led a sub district head. In 2019, the State of Indonesia had 7,252 sub-districts. ${ }^{1}$ Of that number, there sub district located in border area country. Sub-districts located in state border areas in Article 1 Number 6 of the State Territory Law are "Border Areas."

So, only sub district located in border area country on land are border area. Therefore, for convenience in this paper, the author only focuses on sub district located in border area country on land.

Territory of Indonesia includes land area, water area, sea and below it and air space, including all of wealth contained. In addition, paragraph (1) article 6 of State Territory Law states that the boundaries of territory State Indonesia include:

a. On land bordered the territory : Malaysian, Papua New Guinea (PNG), Timor Leste (Timor Timur);

b. In sea bordered the territory : Malaysian, Papua New Guinea (PNG), Singapore, Timor Leste (Timor Timur);

\footnotetext{
${ }^{1}$ https://www.bps.go.id/
}

c. In air following boundaries state sovereignty land, sea, and outer space. ${ }^{2}$

Territorial boundaries on land are boundaries agreed upon by the Dutch East Indies Government and the British Government in Kalimantan and Papua, and the Portuguese Government on Timor Island which subsequently became Indonesian territory based princip uti possidetis juris applicable in international law. Based on this principle, an independent country inherits the territory of its former colonial state.

Boundary Indonesian and Malaysian was established basis of the Dutch East Indies and British Indies Conventions of 1891, 1915, and 1928. The land boundary between Indonesia and Timor Leste was determined on the basis of the Convention on the Delimitation of the Boundaries of the Dutch East Indies and Portugal in 1904 and decision Permanent Court Arbitration (PCA) 1914. Boundary Indonesian and Papua New Guinea (PNG) was established on 1895 based Dutch-British Indies Boundary Treaty. ${ }^{3}$

Boundaries Indonesian state on land bordering Malaysia are in the West Borneo Provinces, East Borneo Province, and North Borneo Province. In

2 See Article 6 paragraph (1) of the State Territory Law.

3 See the Elucidation paragraph (1) article 6 letter a of the State Territory Law. 
particular, West Borneo Province has a land border area which is spread over 5 (five) regencies, namely: Sanggau, Sambas, Sintang, Kapuas Hulu, and Bengkayang. The land border line in West Borneo Province along 966 Kilometers separates territory Republic Indonesia from territory Sarawak, Malaysia. ${ }^{4}$

Sintang Regency is one of the regencies in West Kalimantan Province which is directly adjacent to Sarawak, Malaysia, which is spread over 2 (two) subdistricts, namely: Ketungau Hulu District and Central Ketungau District. ${ }^{5}$ The two sub-districts are subdistricts that are directly adjacent to the State of Malaysia, precisely in the Sri Aman District, a subdistrict located in the State of Sarawak, East Malaysia.

Sub district located in border area country have different characteristics from other sub-districts. In all sub district located in border areas country, there are many residents who go in and out of neighboring countries, so sub district head must be able to instill an attitude of nationalism to the population. Do not let it happen that people love foreign products more than Indonesian products, or prefer Ringgit or Dollars to Rupiah. The task of the sub-district head in the border areas is very difficult and challenging.

The population of Ketungau Hulu and Central Ketungau sub-districts is spread out in 58 villages, each of which is 29 villages in Ketungau Hulu District ${ }^{6}$ and 29 villages in Central Ketungau District. ${ }^{7}$ The population in the two sub-districts in 2019 reached a total of 53,691 people, respectively 22,532 people in Ketungau Hulu District and 31,159 people in Central Ketungau District.

Residents in these two sub-districts are still often in and out of Malaysia. The goal is not to picnic, travel or travel, but solely to meet their needs. There are several factors that cause residents to often go in and out of Malaysia, including:

1. The distance to Malaysia is closer when compared to Sintang City, as the capital of Sintang Regency. The distance from Senaning, the capital of Ketungau Hulu sub-district to Sintang City is about $189 \mathrm{~km},{ }^{8}$ while to Sri Aman, Malaysia it is about $156.8 \mathrm{~km}$. Meanwhile, the distance from Nanga Merakai, the capital of Central Ketungau

\footnotetext{
${ }^{4}$ Management Master Plan State \& Border Area 2011-2014.

5 Sintang Regency in Figures 2020. Central Bureau of Statistics of Sintang Regency. https://sintangkab.bps.go.id.

6 Ketungau Hulu District in Figures 2020.
} Central Bureau of Statistics of Sintang Regency. https://sintangkab.bps.go.id.

7 Central Ketungau District in Figures 2020. Central Bureau of Statistics of Sintang Regency. https://sintangkab.bps.go.id.

8 Sintang Regency in Figures 2020. Central Bureau of Statistics of Sintang Regency. https://sintangkab.bps.go.id.
District to Sintang City is about $99 \mathrm{~km},{ }^{9}$ while to Sri Aman, Malaysia it is $78.3 \mathrm{~km}$.

2. The prices of basic commodities in Sri Aman, Malaysia are cheaper.

Population traffic to neighboring Malaysia is not a desire but a necessity, because conditions in their area (Ketungau Hulu and Ketungau Tengah subdistricts) still lack facilities and infrastructure or public facilities in all fields, such as roads, electricity, educational facilities, health, market, and so on.

The limited conditions finally made the residents look for a way out to venture across to neighboring Malaysia even though they had to walk through jungles and hills or river paths. There is no official border route as an entry point between Indonesia and Malaysia, so the border routes that are often used by residents of the two countries for entry and exit are heavily guarded by the military of each country, Indonesia and Malaysia with the establishment of the Border Security Post (Pos Pamtas) to protect the boundaries of their respective countries.

Residents in the two sub-districts view that neighboring Malaysia provides a lot of their necessities of life, so they often go in and out of Malaysia. So, they travel to Malaysia not for tours or picnics but to survive by selling agricultural and plantation products, shopping to meet household needs and medical treatment when sick. Residents in Ketungau Hulu and Ketungau Tengah sub-districts want their area to be developed that provides various facilities and infrastructure for their survival. This then causes the author's sad attitude towards the fate of the Indonesian population living in the border areas of the country who have not yet enjoyed the comfort of life when the State of Indonesia has entered the age of 75 years of independence.

Seeing the life of the people in the border areas of the country which is still concerning, the sub-district which is part of the district/city area as their place of residence must of course be managed as well as possible. The management of sub-districts located in state border areas must be carried out with clear arrangements which include authority, budget and so on.

Departing from the thought above, the author is interested in explaining it in an article regarding: Departing from the thought above, the author is interested in explaining it in an article regarding :

1. Why is the authority of sub districts in the border areas of the state needed in managing border areas?

2. What is the form of sub district authority in the state border area in managing the border area?

3. What are the factors that hinder the implementation of the authority of sub districts in the border areas of the state in managing border areas?

9 Sintang Regency in Figures 2020. Central Bureau of Statistics of Sintang Regency. https://sintangkab.bps.go.id. 
The purpose of this research is to out how authority sub district in state border area in managing border areas. This issue is important to discuss because the management of sub-districts in the border areas of the country must be carried out with clear authority.

\section{RESEARCH METHOD}

This research is a normative juridical with secondary data is (a) primary legal in form laws and regulations and (b) secondary legal, namely books and journals. Data collection is done through literature study and document study. Data analysis was carried out using aconceptual approach and a statutory approach. The theory used in this study is the theory of border area management.

\section{RESEARCH RESULTS AND DISCUSSION}

\subsection{Theory of Border Area Management}

Stephen B. Jones'withtheory boundary making divides border area management steps into 4 (four) types, namely: Allocation, Delimination, Demarcation, and Administration. [1] The four steps are interrelated and form a series of decisions that are interrelated in their implementation.

Allocation (allocation), is the clarity of the area based on historical and juridical evidence. [2] The scope of the territory is determined based on national law and international law. In Indonesia, the territory of Indonesia is nationally regulated in the provisions of state legislation. The highest reference used is Article $25 \mathrm{~A}$ of the 1945 Constitution, in addition to Law State Territory Number 43 of 2008, Law Ratification UNCLOS Number 17 of 1985, Law Indonesian Waters Number 6 of 1966 [3]. Basically, these rules are used as references to national law within the scope of coverage of the Indonesian state. Meanwhile, in terms of international law, it uses the principle of uti possidetis juris for land areas and the UNCLOS convention for sea areas.

Delimination is the affirmation of border lines through a series of diplomacy based on historical and juridical evidence in the past. ${ }^{10}$ This stage is carried out by identifying overlapping areas or having boundaries with neighboring countries, determining coordinate points and making general illustration maps as a result of the agreement. Then the agreement was strengthened by making an agreement or MoU between the two countries.

Demarcation definement ofstake (boundaries) is a technical process in determining borderpoints which is carried out with a series of activities such as surveys and mapping. ${ }^{11}$ This stage is carried out by placing boundary markers along the boundary lines that have

10 Titik Triwulan Tutik. Restorasi Hukum Tata... Op.Cit., p. 681.

${ }^{11}$ Ibid, p. 682. been agreed with neighboring countries. For the land part, it is done by installing boundary stakes along the boundary line. However, at sea, it is difficult to install boundary signs along the boundary line. Currently only installing a beacon tower as a marker of the boundary between the two countries. [4] The determination and affirmation of state boundaries is very important and urgent. Given the rapid growth and development of development that requires new space for the needs of a country's activities. If there is no confirmation of the territory, it will be threatened to lose or change the boundaries of a country or claim each other's territory by the two bordering countries.

Administration (development management), at this stage development is carried out in the border area by involving multi-sector and integrated planning from various fields, such as politics, social, defense and security, economy, culture, environment, and others. ${ }^{12}$ At this stage, the management of population and resources is also carried out, the division of authority between central and local government, as management CIQ (Custom, Immigration And Quarantine) and others. [5]

Thus the border area can be developed as a densely populated area such as in the district/provincial capital. Knowing the condition of the border area is very important so that its management can be right on target. To determine the condition of the border area using the theory of Stephen B. Jones in managing the border area. Thus, it can be seen which stage the border area belongs to, whether Allocation (allocation), Delimination definement of (boundaries), Demarcation definement of (boundaries), or Administration (management of development). ${ }^{13}$

After knowing which level it is, it will make it easier to manage it. What is clear is that the management carried out is in accordance with the conditions of the border. In general, the problem of Allocation (allocation), Delimination definement of (boundaries), is relatively finished. Thus, border management on land is focused on demarcationdefinement of (boundaries), or administration (management of development). ${ }^{14}$ Handling borders on land is easier because there are physical boundaries so they are easy to handle. Although it is considered easy to handle, until now it has not been able to resolve the consequences of less than optimal management. The state still has to pay attention to and maintain the sovereignty of the border area.

\subsection{Management of State Border Areas in Indonesia}

12 Ludiro Madu, dkk. 2010. Mengelola Perbatasan...Op. Cit., p. 112.

13 Romi Nugroho dan Arditya Wicaksono,

“Menata Sejengkal.... Op. Cit., p. 284.

14 Ludiro Madu, dkk. 2010. Mengelola Perbatasan ... Op. Cit., p. 113. 
Legal system in the world namely Common Law and Civil Law systems. Besides that, there is also a Socialist Law System, which has long been equated with common law and civil law. However, the system is socialist law now in a form of decline that makes it no longer feasible to be analyzed in a position parallel to the two legal systems. [6]

Indonesia's border areas are managed based on statutory regulations. This is because Indonesia adheres to the Civil Law System which always prioritizes the laws and regulations. Peter de Cruz ${ }^{15}$ said that : "Civil law regulations are considered as the main source of law, to which all other sources of law are subordinated, and in certain cases often the only source of law."

Management of state border areas in Indonesia can be seen from the State Territory Law as its juridical basis, namely as follows : ${ }^{16}$

a. Management of state territory with a joint to welfare, security and environmental sustainability. The welfare approach in the sense of efforts to manage the State Territory should provide the maximum benefit for improving the welfare of people living in Border Area. The security approach in the sense of managing the territory of the state is to ensure the territorial integrity and sovereignty of the state as well as the protection of the entire nation. While the approach to environmental sustainability in the sense of border area development that pays attention to aspects of environmental sustainability which is a manifestation of sustainable development.

b. Management of state border areas applies the principle of regional autonomy in managing the development of border areas.

\subsection{Problems in the Management of State Border Areas}

Taking into account the condition of the people in the country's border areas which are still concerning as stated above, it means that the management of the state border areas is currently not well regulated, as follows:

a. Centralized authority.

The granting of authority to Regional Governments to carry out autonomy has been expressly stated in paragraph (2) article 18 of Constitution 1945 which reads: "Provincial, district and city regional governments regulate government affairs themselves according to the principles of autonomy and assistance tasks." However, what later emerged in the Regional Government Law led to a centralized.

Paragraph (2) and (3) article 361 of Law Regional Government states that: "The authority of the Central Government in border areas includes all authorities regarding the management and utilization of

15 Peter de Cruz. 2010. Perbandingan Sistem Hukum...,Op. Cit., p. 66.

${ }^{16}$ See Penjelasan Umum UU Wilayah Negara. border areas in accordance with the provisions of laws and regulations concerning state territory." Then in the next paragraph expands the authority Central Government, namely:

(1) Determination of detailed spatial plans;

(2) Space utilization control and permit; and

(3) Development of regional facilities and infrastructure.

This proves that the Regional Government has not given full authority to carry out regional autonomy in border areas, including the development of human resources for communities in border areas.

As Article 361 paragraphs (4) and (5) contain the Governor as the representative of the Central Government to coordinate the implementation of border area development based on the guidelines set by the Central Government. In coordinating the implementation of border area development as referred to in paragraph (4), the governor as the representative of the Central Government is assisted by the regent/mayor.

The provisions of the article above are not able to make the Regional Government in the region in the border area to do various things as regional autonomy as broadly as possible because it will be very dependent on the Central Government. Although the Governor is the representative of the Central Government, of course the role of the Governor can only carry out what is determined by the Central Government. Of course, this will not lead to significant development in border areas and has implications for the lack of facilities and infrastructure, for example in the fields of education and health.

Regional autonomy largely depends on the extent to which the central government has good intentions to empower local governments through the granting of greater authority. This is because, with the decentralization of power and authority from the center to the regions in a state of ongoing autonomy, it will be very important in achieving the goals of decentralization itself. At the lowest level, autonomy means referring to the manifestation of the free will inherent in human beings as one of the most precious gifts from God. Autonomy is the right of the people to regulate the government in the region in their own way in accordance with the law, customs and manners. This kind of autonomy is called basic andautonomy indigenous. In addition, autonomy as a manifestation of decentralization is never separated from the aspects of democracy which are the core of autonomy itself. [7]

b. There is no clear division of authority regarding the management of state border areas.

According to Bagir Manan, authority is both a right and an obligation (rechten en plichten). [8] Meanwhile, according to Soerjono Soekanto, authority is the power that exists in a person or group of people who receive recognition from the community. [9] According to Jum Anggraini, authority is defined as: First, what is called "formal power" namely power that comes from legislative power (given by law) or from executive administrative power. Second, authority can 
consist of several powers. Third, authority is power over a certain group of people over the government. [10] The authority that exists in a state institution is very important in running the wheels of government.

Currently, there are 2 (two) laws, the most important of which regulate the management of state border areas, namely: the State Territory Law and the Regional Government Law. However, the two laws do not clearly stipulate the authority to manage state border areas.

The State Territory Law regulates the respective authorities of the Government, Provincial Government and Regency/City Government, as regulated in Articles 9 to 12 of the State Territory Law. Whereas in the Regional Government Law, the authority to manage state border areas is only given to the central government. In addition to the authority stated in the Law, the Regional Government becomes the authority of the region, without mentioning what the authority is. The governor coordinates the implementation of border area development based on the guidelines set by the central government assisted by the regent/mayor and in providing assistance in implementing the development of the border area, the regent/mayor assigns the sub-district head in the border area. For more details, see Article 361 of the Regional Government Law.

So, the two laws (State Territory Law and Regional Government Law) do not clearly divide the authority to manage border areas. The State Territory Law stipulates the authority of the government, provincial government and district/city governments, but the Regional Government Law only stipulates the authority of the central government. Thus, there is a lack of clarity of authority and overlapping.

c. The existence of the Regional Border Management Agency (BPPD) as the State Border Area Management Agency The State.

Territory Law in its regulation regarding the management of border areas regulates the institutions that manage the country's border areas, namely the National Border Management Agency (BNPP) and the Regional Border Management Agency (BPPD). The institution is placed in Chapter VI starting from Article 14 to Article 18.

The logical consequence of this arrangement is that the BNPP is formed which is stipulated in Presidential Regulation of the Republic of Indonesia Number 12 of 2010 concerning the National Border Management Agency, which has been amended by Presidential Regulation of the Republic of Indonesia Number 44 of 2017 and the establishment of a Regional Border Management Agency (BPPD) which is stipulated by a regional regulation (Perda) based on the Regulation of the Minister of Home Affairs Number 2 of 2011 concerning Guidelines for the Establishment of a Regional Border Management Agency, which has been replaced by Regulation of the Minister of Home Affairs of the Republic of Indonesia Number 140 of
2017 concerning the Establishment of a Regional Border Management Agency.

The Sintang Regency area currently has a BPPD whose establishment is based on the Sintang Regency Regional Regulation Number 5 of 2011 concerning the Establishment of the Sintang Regency Border Management Agency (Sintang Regency Regional Gazette of 2011 Number 5, and Supplement to the Sintang Regency Regional Gazette Number 5).

The existence of the Border Management Agency in the regions is only limited to providing proposals regarding the development of border areas, monitoring the development of border area development carried out by the central government as well as evaluating and providing input to the central government regarding development and policy making in border areas.

The authority possessed by regional managers will not have an impact on the development of border areas because to make policies and so on, they must wait for coordination from the center. [11]

d. The Authority of Sub-Districts Located in State Border Areas is Not Clear and Firm.

Sub districts located in state border areas are border areas as stated in Article 1 Point 6 of the State Territory Law, namely: Indonesia and other countries, in terms of state boundaries on land, the border areas are in the sub districts.

Because the sub-districts located in the border areas of the state are border areas, the sub-districts should be given the authority to manage border areas. Unfortunately, nowadays sub-districts located in the border areas of the country are only given authority from the regents/cities or ministries/non-ministerials in the form of assistance assignments. It reads in full as follows:

Article 361 paragraph (6) of :

the Regional Government Law

In providing assistance for the implementation of border area development as referred to in paragraph (5), the regent/mayor shall assign the sub-district head in the border area.

In the article, the sub-district head as the head of the sub-district is given an assignment by the regent/city to assist the implementation of border area development.

The authority that comes from regents/municipalities or ministries/non-ministerials in the form of assistance assignments is also stated in Government Regulation of the Republic of Indonesia Number 17 of 2018 concerning Sub-districts, as follows:

\section{Article 12}

(1) Camats in state border areas whose territory is outside the state border post can assist supervision in the field of immigration, customs, and quarantine assigned by the relevant ministry/nonministerial government agency to the regent/mayor. 
(2) The sub-district head in the state border area may be given certain authority according to the assignment from the Central Government in stages in the management and utilization of the state border area in accordance with the provisions of the legislation.

In the article, the sub-district head as the head of the sub-district whose territory is outside the border crossing post may be assigned by the regent/city to assist in supervision in the fields of immigration, customs, and quarantine. In addition, certain powers may be given according to the assignment from the Central Government in stages in the management and utilization of state border areas.

Based on the description above, it can be understood that the authority of sub-districts located in the border areas of the country is still narrow and not yet firm with the words/phrases "...can help..." and "...can be given certain authorities... The use of the word "can" is a relative action, yes or no. It is very different when using the word "must" which is an absolute or must action.

From this arrangement, it appears that the legislators have not understood the importance of subdistricts located in the state border areas in managing border areas.

4. Recommendation: Establishing a Special Border Area (DKP) as a middle ground.

State Territory Law in Article 1 Number 6 states that: "Border areas are part of the territory of the state which is located on the inside along the boundaries of Indonesia's territory with other countries, in terms of state boundaries in land, the border area is in the sub district." According to Article 1 number 24 of the Regional Government Law, Article 1 number 24 that: states " $a$ sub-district or what is called by another name is part of the territory of a district/city area led by a sub-district head." Based on this provision, the logical consequence is that the sub-districts on the state borders on land are the locus (places) of the border areas as part of the territory of the district/city area led by the subdistrict head. Currently, sub districts on land borders have authority from the government, provincial government and district/city governments, either in the form of delegation or assignment. Seeing the authority possessed by the sub-district, it is only natural that the state border area cannot develop and progress. Therefore, it is time for the sub-districts on the state boundaries on land to be designated as Border Special Regions or DKP. The establishment of DKP is based on national strategic considerations, as regulated in Article 49 paragraph (1) of the Regional Government Law which reads : "The establishment of regions based on considerations of national strategic interests applies to border areas, outer islands, and certain regions to safeguard the interests and sovereignty of the Unitary Republic Indonesia. Indonesia." The formation of the DKP is carried out with a mechanism that has been regulated by the Regional Government Law.
So, from this description, Ketungau Hulu Subdistrict and Central Ketungau Subdistrict, Sintang Regency, West Kalimantan Province, which are border areas, should become "Special Border Areas" named DKP Ketungau.

Sub districts located in the border areas of the country are the front page of the Indonesian state which must be strictly guarded from the traffic of people and goods, because if not, it can threaten the sovereignty of the Unitary State of the Republic Indonesia (NKRI) and smuggling of goods and people occurs. Therefore, the management of the border area must be carried out as well as possible.

\section{CONCLUSION}

The condition of state border areas in Indonesia which is still concerning today is due to the centralized authority of the central government and the overlapping authorities of both the State Territory Law and the Regional Government Law so that it is unclear which authority will be used from the two laws. the. In addition, there are regulations regarding institutions that manage border areas, namely BPPD in the State Territory Law which are coordinating so that they do not have an impact on implementation and the authority for sub-districts in the state border area is not yet clear in managing border areas.

\section{REFERENCES}

[1] Ludiro Madu. 2010. Mengelola Perbatasan Indonesia Di Dunia Tanpa Batas : Isu, Permasalahan Dan Pilihan Kebijakan. Yogyakarta : Graha Ilmu, 2010., p.111.

[2] Titik Triwulan Tutik. 2017. Restorasi Hukum Tata Negara Indonesia Berdasarkan Undang-Undang Dasar Negara Republik Indonesia Tahun 1945. Depok : Prenadamedia Group., p.681.

[3] Budi Hermawan Bangun. 2017. "Konsepsi Dan Pengelolaan Wilayah Perbatasan Negara. Perspektif Hukum Internasional," TanjungPura Law Journal, vol. 1, no. 1, p. 55.

[4] Suryo Sakti Hadiwijoyo. 2012. Aspek Hukum Wilayah Negara Indonesia. Yogyakarta : Graha Ilmu., p. 17.

[5] Romi Nugroho dan Arditya Wicaksono. 2013. "Menata Sejengkal Tanah Di Ujung Batas Negara (Sinkronisasi Dan Koordinasi Lintas Kementerian Dan Lembaga Dalam Percepatan Pembangunan," Jurnal Jejaring Administrasi Publik, vol. V, no. 1, p. 284.

[6] P. Cruz de. 2010. Perbandingan Sistem Hukum. Civil Law, Common Law dan Socialist Law. Cetakan I, Bandung: Nusa Media., p. 2.

[7] Rudy. 2012. Hukum Pemerintahan Daerah Perspektif Konstitusionalisme Indonesia. Bandar Lampung: Indepth Publishing., p. 31. 
[8] Bagir Manan. 2000. "Wewenang Provinsi, Kabupaten/Kota Dalam Rangka Otonomi Daerah," dalam Fakultas Hukum Universitas Padjajaran, Bandung., p.1-2.

[9] Soerjono Soekanto. 2013. Pokok-Pokok Sosiologi Hukum. Jakarta : Raja Grafindo Persada., p. 91-92.

[10] Jum Anggraini. 2012. Hukum Administrasi Negara. Yogyakarta : Graha Ilmu, p.87.

[11] Nur Syamsiah. 2018. Kewenangan Badan Nasional Pengelola Perbatasan (BNPP) Dalam Mengelola Kawasan Perbatasan Darat Di Desa Temajuk Kecamatan Paloh Kabupaten Sambas, Kalimantan Barat. Surabaya : Universitas Islam Negeri Sunan Ampel., p. 107-108. 